\title{
Front Matter: Volume 9824
}

, "Front Matter: Volume 9824," Proc. SPIE 9824, Chemical, Biological, Radiological, Nuclear, and Explosives (CBRNE) Sensing XVII, 982401 (1 August 2016); doi: 10.1117/12.2245233

SPIE. Event: SPIE Defense + Security, 2016, Baltimore, MD, United States 


\title{
PROCEEDINGS OF SPIE
}

\section{Chemical, Biological, Radiological, Nuclear, and Explosives (CBRNE) Sensing XVII}

\author{
Augustus W. Fountain III \\ Editor
}

18-20 April 2016

Baltimore, Maryland, United States

Sponsored and Published by

SPIE 
The papers in this volume were part of the technical conference cited on the cover and title page. Papers were selected and subject to review by the editors and conference program committee. Some conference presentations may not be available for publication. Additional papers and presentation recordings may be available online in the SPIE Digital Library at SPIEDigitallibrary.org.

The papers reflect the work and thoughts of the authors and are published herein as submitted. The publisher is not responsible for the validity of the information or for any outcomes resulting from reliance thereon.

Please use the following format to cite material from these proceedings:

Author(s), "Title of Paper," in Chemical, Biological, Radiological, Nuclear, and Explosives (CBRNE) Sensing XVII, edited by Augustus W. Fountain III, Proceedings of SPIE Vol. 9824 (SPIE, Bellingham, WA, 2016) Six-digit Article CID Number.

ISSN: 0277-786X

ISSN: 1996-756X (electronic)

ISBN: 9781510600652

Published by

SPIE

P.O. Box 10, Bellingham, Washington 98227-0010 USA

Telephone +1 3606763290 (Pacific Time) · Fax +1 3606471445

SPIE.org

Copyright (c) 2016, Society of Photo-Optical Instrumentation Engineers.

Copying of material in this book for internal or personal use, or for the internal or personal use of specific clients, beyond the fair use provisions granted by the U.S. Copyright Law is authorized by SPIE subject to payment of copying fees. The Transactional Reporting Service base fee for this volume is $\$ 18.00$ per article (or portion thereof), which should be paid directly to the Copyright Clearance Center (CCC), 222 Rosewood Drive, Danvers, MA 01923. Payment may also be made electronically through CCC Online at copyright.com. Other copying for republication, resale, advertising or promotion, or any form of systematic or multiple reproduction of any material in this book is prohibited except with permission in writing from the publisher. The CCC fee code is 0277-786X/16/\$18.00.

Printed in the United States of America.

Publication of record for individual papers is online in the SPIE Digital Library.

\section{SPIE. DIGITAL}

Paper Numbering: Proceedings of SPIE follow an e-First publication model. A unique citation identifier (CID) number is assigned to each article at the time of publication. Utilization of CIDs allows articles to be fully citable as soon as they are published online, and connects the same identifier to all online and print versions of the publication. SPIE uses a six-digit CID article numbering system structured as follows:

- The first four digits correspond to the SPIE volume number.

- The last two digits indicate publication order within the volume using a Base 36 numbering system employing both numerals and letters. These two-number sets start with $00,01,02,03,04$, $05,06,07,08,09,0 A, 0 B \ldots$. OZ, followed by 10-1Z, 20-2Z, etc. The CID Number appears on each page of the manuscript. 


\title{
Contents
}

\author{
vii Authors \\ ix Conference Committee \\ xi Introduction
}

INTEGRATED PHOTONICS SENSING OF CBRNE THREATS

982402 Chemical and biological sensing applications of integrated photonics with an introduction to the American Institute for Manufacturing Integrated Photonics (AIM Photonics) [9824-1]

982403 Integrated mid-infrared photonic circuits for label-free biochemical sensing [9824-2]

982404 Nanophotonic waveguides for chip-scale Raman spectroscopy: theoretical considerations [9824-3]

982405 A label-free optical biosensor for serotyping "unknown" influenza viruses [9824-4]

THE FUTURE OF CBRNE SENSING: APPLICATIONS OF QUANTUM SENSING

982407 Photon-sparse microscopy: trans-wavelength ghost imaging (Invited Paper) [9824-6]

\section{CURRENT PROGRESS IN CBRNE SENSING I}

$9824 \mathrm{OB} \quad$ High sensitivity stand-off detection and quantification of chemical mixtures using an active coherent laser spectrometer (ACLaS) (Invited Paper) [9824-11]

9824 OC Stand-off detection of explosives and precursors using compressive sensing Raman spectroscopy [9824-12]

9824 OD Ultraviolet Raman scattering from persistent chemical warfare agents [9824-13]

9824 OE Recent development of two new UV Raman standoff explosive detection systems [9824-14]

9824 OF Trace material detection of surfaces via single-beam femtosecond MCARS (Best Paper Award) [9824-15] 
9824 OG Applications of spatially offset Raman spectroscopy to defense and security (Invited Paper) [9824-16]

$9824 \mathrm{OH} \quad$ New designs for portable Raman instrumentation in defense applications (Invited Paper) [9824-17]

9824 Ol Bottled liquid explosive scanner by near infrared [9824-18]

9824 0J Application of the modified transient plane source technique for early detection of liquid explosives [9824-19]

$9824 \mathrm{OL}$ Characterization and control of tunable quantum cascade laser beam parameters for stand-off spectroscopy (Best Paper Award) [9824-21]

\section{CURRENT PROGRESS IN CBRNE SENSING II}

9824 OM Standoff photoacoustic detections with high-sensitivity microphones and acoustic arrays (Invited Paper) [9824-22]

$9824 \mathrm{ON} \quad$ Progress towards a $\mathrm{LaBr}_{3}$-based associated particle imaging test bed for contraband detection and bulk materials analysis [9824-23]

982400 Standoff photoacoustic sensing of trace chemicals by laser Doppler vibrometer [9824-24]

9824 OP Spectral imaging of chemical compounds using multivariate optically enhanced filters integrated with InGaAs VGA cameras [9824-25]

\section{CURRENT PROGRESS IN CBRNE SENSING III}

$98240 Q$ Chemical and explosive detection with long-wave infrared laser induced breakdown spectroscopy [9824-26]

9824 OR Photoacoustic spectroscopy for trace vapor detection and standoff detection of explosives [9824-27]

9824 OS Bioaerosol detection using single particle triggered LIBS [9824-28]

\section{ADVANCES IN ALGORITHMS FOR CBRNE SENSING}

9824 OU Detection of gaseous plumes in airborne hyperspectral imagery [9824-30]

9824 OV Hyperspectral image analysis for standoff trace detection using IR laser spectroscopy [9824-31] 
9824 OW Analysis of analytic nonresonant background removal algorithm for MCARS spectra [9824-32]

9824 OY Standoff detection: distinction of bacteria by hyperspectral laser induced fluorescence [9824-34]

$9824 \mathrm{OZ}$ Analysis of continuum generation in bulk materials with a femtosecond Ti:Sapph laser [9824-35]

RADIOLOGICAL AND NUCLEAR SENSING

982411 Design and growth of novel compounds for radiation sensors: multinary chalcogenides [9824-37]

982412 Tritium-powered radiation sensor network [9824-38]

982414 Low-cost fabrication of high efficiency solid-state neutron detectors [9824-40]

982415 Raman spectroscopy for analysis of thorium compounds [9824-41]

\section{CURRENT PROGRESS IN CBRNE SENSING IV}

982416 Real-time short-wave infrared hyperspectral conformal imaging sensor for the detection of threat materials [9824-42]

982417 Airborne pipeline leak detection: UV or IR? [9824-43]

982418 A method to control the polymorphic phase for RDX-based trace standards [9824-44]

982419 Persistence of explosives under real world conditions [9824-45]

9824 1A A new approach for detection of explosives based on ion mobility spectrometry and laser desorption/ionization on porous silicon [9824-46]

POSTER SESSION

9824 1B Eye-safe infrared laser-induced breakdown spectroscopy (LIBS) emissions from energetic materials [9824-47] 
Proc. of SPIE Vol. $9824982401-6$

Downloaded From: https://www.spiedigitallibrary.org/conference-proceedings-of-spie on 26 Apr 2023 Terms of Use: https://www.spiedigitallibrary.org/terms-of-use 


\section{Authors}

Numbers in the index correspond to the last two digits of the six-digit citation identifier (CID) article numbering system used in Proceedings of SPIE. The first four digits reflect the volume number. Base 36 numbering is employed for the last two digits and indicates the order of articles within the volume. Numbers start with 00, 01, 02, 03, 04, 05, 06, 07, 08, 09, 0A, OB...0Z, followed by 10-1Z, 20-2Z, etc.

Ackermann, Sarah L. G., OJ

Adams, Katy, 19

Agassi, Eyal, OU

Ågren, Matilda, OC

Allard, Martin, 17

Argirakis, Brittney L., 18

Arnold, Brad, 11

Aspden, Reuben S., 07

Babin, François, 17

Babnick, Robert, OE

Bateman, Robert, 0J

Bhat, Ishwara B., 14

Bickford, Justin, 02

Bowman Pilkington, Sherrie, OF, OW, OZ

Boyd, Robert W., 07

Brady, John J., 18

Brown, Ei E., OQ, 1B

Buller, Gerald S., 07

Buller, Shane, $\mathrm{OH}$

Butschek, L., OV

Carroll, J. J., ON

Carron, Keith, $\mathrm{OH}$

Chamberland, Martin, OU

Chiara, C. J., ON

Chistyakov, Alexander, 1A

Choa, Fow-Sen, OM, 11

Cooper, Justin L., OE

Dahal, Rajendra, 14

Danon, Yaron, 14

Demaree, J. D., ON

Dovzhenko, Dmitriy, $1 \mathrm{~A}$

Dreyhaupt, A., OV

Duschek, Frank, OY

Eichstaedt, Holger, OU

English, Erik, 14

Fellner, Lea, OY

Fischer, Thomas, 19

Ford, Alan R., OE

Fu, Y., $0 O$

Fuchs, F., OV

Furstenberg, Robert, OL, 19

Gagnon, Marc-André, OU

Gemmell, Nathan R, 07

Glimtoft, Martin, OC

Gordon, Alexander D., 18

Gradmark, Per-Åke, OS

Grahmann, J., OV

Gravel, Jean-François, 17

Grünewald, Karin M., OY
Guardala, N. A., ON

Guicheteau, Jason, 02, 0G

Gupta, Deepa, OM

Hadfield, Robert H., 07

Handke, Jürgen, OY

Harris, Adam, OJ

Hausmann, Anita, OY

Hella, Mona M., 14

Henry Dunand, Carole, 05

Herrera, Francisco, OE

Hirsch, Eitan, OU

Holmstrom, Scott A., 04

Holthoff, Ellen L., OR

Hommerich, Uwe H., OQ, IB

Hopkins, Adam J., OE

Hopkins, Rebecca, OG

Howard, Andrew, 19

Howle, Christopher R., OJ

$\mathrm{HU}, \mathrm{Q} ., 00$

Huang, Kuan-Chih, 14

Hugger, S., OV

Itozaki, Hideo, 0 I

Jacksen, Niels, OP

Jarvis, J., OV

Jin, Feng, OQ, 1B

Johnson, Timothy J., 15

Julich, Sandra, OY

Karlsson, Annelie, OS

Katsis, Dimos, 12

Kendziora, Christopher A., OL, 19

Khurgin, Jacob B., 04, OM

Kirkwood, Robert A., 07

Kotkovskii, Gennadii, 1 A

Kozak, Dmitry A., 04

Kullander, Fredrik, OD

Kumi-Barimah, Eric, $O Q$

Kuzishchin, Yury, IA

Landström, Lars, OD, OS

Lareau, Richard T., 18

Larsson, Anders, OS

Lee, Linda, $0 \mathrm{~J}$

Lin, Pao Tai, 03

Litz, Marc S., ON, 12

Liv, H., $0 \mathrm{O}$

LU, James J.-Q., 14

MacLeod, Neil A., OB

Marcus, Logan S., OR

Marsh, J. C., ON

Martynov, Igor, IA 
McGill, R. Andrew, 04, OL, 19

Mertens, Lena, 07

Miller, Benjamin L., 05

Morris, Peter A., 07

Nagaradona, Teja, 11

Nelson, Matthew P., 16

Nguyen, Viet, OL, 19

Nordberg, Markus, OC

Olsen, Khris B., 15

Ostendorf, R., OV

Östmark, Henric, OC

Padgett, Miles J., 07

Papantonakis, Michael R., OL, 19

Pargmann, Carsten, $\mathrm{OY}$

Pellegrino, Paul M., OF, OR, OW, OZ

Pohl, Ken, OE

Priore, Ryan J., OP, 16

Profeta, Luisa T. M., OE

Pruessner, Marcel W., 04

Rabinovich, William S., 04

Ray, Bryan, $\mathrm{OH}$

Roberson, Stephen D., OF, OW, OZ

Ruggeri, Alessandro, 07

Russo, Johnny A., 12

Samuels, Alan C., OM, OQ, 1B

Sandoval, Juan, $\mathrm{OE}$

Shi, Lei, 16

Singh, N. B., 11

Smith, Barry T., 18

Stievater, Todd H., 04

Strickland, Aaron, $\mathrm{OH}$

Su, Ching-Hua, 11

Su, Yin-Fong, 15

Svanqvist, Mattias, OC

Tanner, Michael G., 07

Tasca, Daniel S., 07

Tomaso, Herbert, OY

Tosi, Alberto, 07

Treado, Patrick J., 16

Trivedi, Sudhir B., OM, OQ, 1B

Vunck, Darius, OE

Wagner, J., OV

Walter, Arne, OY

Wang, Chen-Chia, OM

Wästerby, Pär, OD

Waterbury, Rob, OE

Weidmann, Damien, OB

Weltz, Adam, 14

Wilson, Patrick, 05

Wu, Jia-Woei, 14

Yang, Clayton S.-C., OQ, 1B

Yang, Q., OV

Zbur, Lucas, 16

Zhang, Hanyuan, 05 


\section{Conference Committee}

Symposium Chair

David A. Logan, BAE Systems (United States)

Symposium Co-chair

Donald A. Reago Jr., U.S. Army Night Vision \& Electronic Sensors Directorate (United States)

Conference Chair

Augustus Way Fountain III, U.S. Army Edgewood Chemical Biological Center (United States)

Conference Program Committee

Sylvie Buteau, Defence Research and Development Canada, Valcartier (Canada)

James P. Carney, Sandia National Laboratories (United States)

Christopher C. Carter, Johns Hopkins University Applied Physics Laboratory, LLC (United States)

Henry Chen, Brimrose Corporation of America (United States)

Darren K. Emge, U.S. Army Edgewood Chemical Biological Center (United States)

Jason A. Guicheteau, U.S. Army Edgewood Chemical Biological Center (United States)

Chris R. Howle, Defense Science and Technology Laboratory (United Kingdom)

Harry Ing, Bubble Technology Industries, Inc. (Canada)

Timothy J. Johnson, Pacific Northwest National Laboratory (United States)

Aaron LaPointe, U.S. Army RDECOM CERDEC NVESD (United States)

Paul M. Pellegrino, U.S. Army Research Laboratory (United States)

Cynthia R. Swim, U.S. Army Edgewood Chemical Biological Center (United States)

Christian Whitchurch, Defense Threat Reduction Agency

(United States) 


\section{Session Chairs}

1 Integrated Photonics Sensing of CBRNE Threats

Jason A. Guicheteau, U.S. Army Edgewood Chemical Biological Center (United States)

2 The Future of CBRNE Sensing: Applications of Quantum Sensing Christopher R. Howle, Defence Science and Technology Laboratory (United Kingdom)

3 Current Progress in CBRNE Sensing I

Jason A. Guicheteau, U.S. Army Edgewood Chemical Biological Center (United States)

4 Optical Methods for Security Applications

Jason A. Guicheteau, U.S. Army Edgewood Chemical Biological Center (United States)

5 Current Progress in CBRNE Sensing II

Aaron LaPointe, U.S. Army RDECOM CERDEC NVESD (United States)

6 Current Progress in CBRNE Sensing III

Christopher C. Carter, Johns Hopkins University Applied Physics Laboratory, LLC (United States)

7 Chemical Detection: Joint Session with Conferences 9823 and 9824 Vincent P. Schnee, U.S. Army RDECOM CERDEC NVESD (United States)

Anthony A. Faust, Defence Research and Development Canada, Suffield (Canada)

8 Advances in Algorithms for CBRNE Sensing

Darren K. Emge, U.S. Army Edgewood Chemical Biological Center (United States)

9 Radiological and Nuclear Sensing

Henry Chen, Brimrose Corporation of America (United States)

10 Current Progress in CBRNE Sensing IV

Paul M. Pellegrino, U.S. Army Research Laboratory (United States) 


\section{Introduction}

The 17th meeting of the CBRNE Sensing Conference met as part of the 2016 SPIE Defense + Commercial Sensing (DCS) Symposium in Baltimore, MD. The Conference extended over the course of three days and 10 sessions, one of which for the first time was held jointly with the "Detection and Sensing of Mines, Explosive Objects, and Obscured Targets XXI" Conference. This year we initiated two new sessions. The first was "Integrated Photonics Sensing of CBRNE Threats". This session highlighted recent advances in chemical and biological sensing applications of integrated photonics coming out of the American Institute for Manufacturing Integrated Photonics (AIM Photonics). The second new session "Applications of Quantum Sensing" looks to explore how advances in Quantum Optics can help solve key detection challenges for the CBRNE community. We plan to continue these sessions and open up new ones as the Conference travels with the 2017 SPIE DCS Symposium to Anaheim, California.

Key Papers and Highlights:

Pao Tai Lin of Texas A\&M University presented interesting work on decreasing the size of detectors on a chip. The work increased the sensitivity for chemical detection by over 50 times. The device was able to differentiate multiple liquids (nbromohexane, tolvene, isopropanol, etc.) as well as the individual concentrations of multiple liquids (acetonitrile and ethanol) in a solution. A clear summary from the basic science and technology to the nanoengineering of the device was presented, and this research could be transitioned into smaller platforms for chemical and explosive weapon material detection.

Rebecca J. Hopkins of the Defence Science and Technology Laboratory presented a talk on the non-destructive detection and identification of samples spatially offset Raman spectroscopy (SORS). These samples can originate from security and defense applications as well as forensic science applications. Their current SORS methodology can reach up through $3 \mathrm{~mm}$ of polyvinyl chloride (PVC) pipe.

Matthew P. Nelson of Chemlmage Corporation presented on their work of a realtime, adaptable, compressive sensing short-wave infrared hyperspectral imaging technology. This technology, dubbed Reconfigurable Conformal Imaging Sensor, could be used as a stand-off detector for trace detection of narcotics, explosives, chemical warfare agents, and other contraband on the surfaces of vehicles and walls.

Once again I want to thank my committee who really makes this conference happen. There is no way I could review all the abstracts and proceedings papers or host all the sessions without them. I am confident that this conference remains 
the most important means of bringing together the leaders in the field of CBRNE sensing from every sector; government, academia and industry. I am already excited about next year's conference and the new developments it will report on.

Augustus W. Fountain III 